\title{
The History and Future Challenges of Calcined Petroleum Coke Production and Use in Aluminum Smelting
}

\author{
LES EDWARDS ${ }^{1,2}$ \\ 1.-Rain CII Carbon, Covington, LA 70433, USA. 2.-e-mail: ledwards@raincii.com
}

Calcined petroleum coke is used for the production of carbon anodes in the Hall-Héroult aluminum smelting process due to a combination of low impurity levels, ready availability, and relatively low cost. This article provides a review of the history and use of calcined petroleum coke for anode production and describes the different calcining technologies used by the industry. The article discusses the impact of changes in crude oil quality and refining economics over the last 10 years as well as the impact on green petroleum coke quality and availability. The industry has adapted well to quality changes in recent times, and the blending of different quality cokes by smelters is becoming increasingly important. The world has a plentiful supply of green petroleum coke, but the next wave of aluminum smelting capacity growth will put further pressure on the supply of the higher quality cokes traditionally favored by the industry.

\section{INTRODUCTION}

Calcined petroleum coke (CPC) has been used for more than 120 years to produce the carbon anodes used in the Hall-Héroult aluminum electrolysis process. Several other forms of carbon were tested in the early stages, but none proved to have the right combination of low impurity levels, relatively low cost, and ready availability. Prebaked anodes are produced with $55-65 \%$ CPC, $13-15 \%$ coal tar pitch binder, and $20-30 \%$ recycled anode butts. The anodes are consumed at a net consumption rate of approximately $400 \mathrm{~kg}$ carbon/ton aluminum for modern smelting cells according to reaction 1 . They provide an important source of heat for the electrolysis process, reducing the cell voltage and overall energy requirement relative to cells operating with nonconsumable anodes. ${ }^{1}$

$$
2 \mathrm{Al}_{2} \mathrm{O}_{3}+3 \mathrm{C}=4 \mathrm{Al}+3 \mathrm{CO}_{2}
$$

CPC is produced by heating or calcining green petroleum coke (GPC) at temperatures greater than $1200^{\circ} \mathrm{C}$. The production of GPC has remained essentially the same since 1929 when the modern delayed coking process was born. This was followed in 1935 by the development of the rotary kiln calcining process, which is the most commonly used technology in the Western world. CPC production has increased significantly in China over the last 10 years, and shaft calcining is the dominant technology used in this region. The aluminum industry has had a ready supply of good-quality GPC and CPC for many years, but the situation has become more challenging over the last 10 years due to a general trend toward higher impurity levels resulting from changes in crude and refining economics.

This article will review the history of GPC and CPC production and its use in aluminum smelting and provide comments on current and future challenges.

\section{Early History}

An excellent review of the history of aluminum production is provided in the Hall-Héroult Centennial book, ${ }^{2}$ which also includes a chapter on anode production. It was fortuitous that petroleum coke had been discovered about 30 years before Hall and Héroult made their independent discoveries on producing aluminum. Work had already been done on developing coke as a filler material in carbon products by Charles Brush and Washington Lawrence in $1877 .{ }^{3}$ Brush discovered that calcining coke prior to forming pitch-bonded shapes produced better quality carbons, and Hall used electrodes 


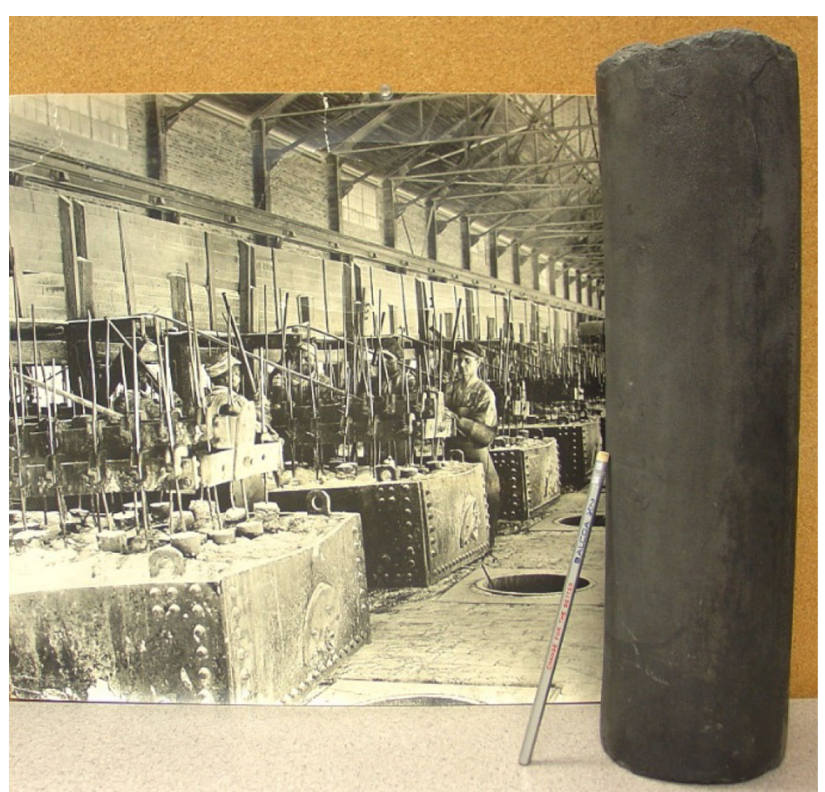

Fig. 1. Early generation Alcoa Tennessee anode (5" diam. $\times 18^{\prime \prime}$ long) in foreground with potroom photo in background (courtesy Steve Lindsay, Alcoa).

supplied by Brush in his early work. In Europe, purified anthracite was believed to have been used as an alternative to CPC during these first years of production.

The commercial production of aluminum by the Pittsburgh Reduction Company (later Alcoa) used carbon anodes made from CPC produced nearby by the Faraday Carbon Company. An early generation anode from the Alcoa Tennessee smelter, circa 1926, is shown in Fig. 1. The anode has a fine grain texture suggesting that the CPC was pulverized first. The slightly bent shape and presence of longitudinal score marks on the external surface is consistent with an extrusion process for forming.

\section{Green Petroleum Coke Production}

GPC production began as early as the 1860 s in the United States and went through many process changes until 1929, when Standard Oil developed the delayed coking process. A good review of the history and production of GPC can be found in the tutorial by Ellis and Paul. ${ }^{4}$ Delayed coking is a "carbon rejection" process used to upgrade the heavy residuum or resid from the bottom of vacuum distillation towers and other refinery process units. Delayed coking significantly increases the recovery of valuable gas and liquid products such as gas, gasoline, gas oils, and so on, as a result of the higher temperatures (approximately $500^{\circ} \mathrm{C}$ ) and more severe thermal treatment. This causes some of the larger, higher molecular weight hydrocarbons to crack into smaller molecules that are then recovered in a fractionator. Polymerization and cross-linking reactions lay down a solid residue of carbon referred to as GPC.
A delayed coker uses vertical drums in a semicontinuous process, as shown in Fig. 2. While one drum is being filled with hot resid and forming coke, solid coke is cut out of the other drum using a high pressure water jet. Not all refineries have delayed cokers, and some produce asphalt or sell resid into the fuel oil market. A typical refinery flow sheet with a delayed coker is shown in Fig. 3. The economic value of GPC is relatively low $(2-3 \%)$ compared with the value of the liquid and gaseous products (97-98\%), so GPC is considered a byproduct at best, for most refineries.

Oil refineries that process heavy crude oils (those with a high specific gravity or low API gravity) produce more resid, and for this reason, delayed cokers are common in these refineries. They produce a greater volume of GPC relative to those running a lighter crude blend. Most GPC (approximately 75\%) is sold as a fuel for power generation and cement production, but the higher quality GPC (lower sulfur and trace metals) is sold to the calcining industry. The global production of GPC was around 115 million DMT (dry metric tons) in 2013 with around 54 million DMT produced in the United States.

\section{GPC Properties}

GPC has several different structural forms commonly referred to as needle coke, sponge coke, and shot coke. Crude oil quality plays a major role in determining which of these is produced, although the coker operation can also play a role. ${ }^{5}$ Figure 4 compares the typical structures of calcined needle, sponge coke, and shot coke with their optical textures, which can be viewed when looking at polished cross-sections under polarized light with an optical microscope. 6,7

Needle coke is a premium product with very low $\mathrm{S}$ and impurity levels and a highly layered or anisotropic structure. It has a low coefficient of thermal expansion $\left(\mathrm{CTE}<2.0 \times 10^{-6} / \mathrm{K}\right)$, making it the material of choice for the production of the graphite electrodes used in steel-producing electric arc furnaces. Needle coke is produced from highly aromatic feedstocks such as decant or slurry oil produced in a fluid catalytic cracker.

Sponge coke is the preferred structure for anode production and CTEs are typically in the range of $3.5-4.8 \times 10^{-6} / \mathrm{K}$. It has a mixed optical texture with a wide range of domain sizes. The open porosity in sponge coke allows good pitch penetration during mixing, and a mechanically strong, interlocking structure develops after anode baking. Shot coke has a characteristic spherical particle shape and a dense, highly isotropic texture sometimes referred to as a granular texture. Shot coke has a high CTE (>5.5) and typically higher levels of sulfur and trace metal impurities, particularly $\mathrm{V}$ and Ni. It is formed from crudes with high levels of 

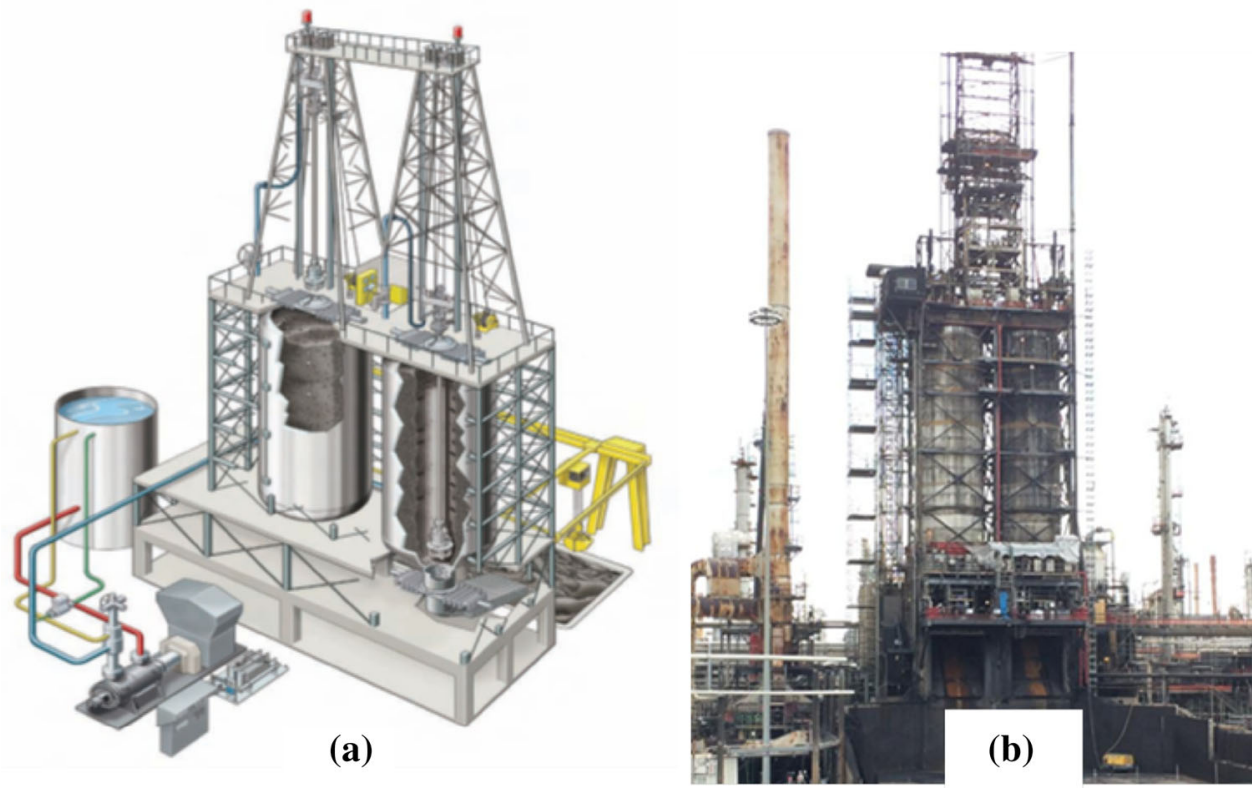

Fig. 2. Delayed coker operation: schematic (a) and delayed coker (b).

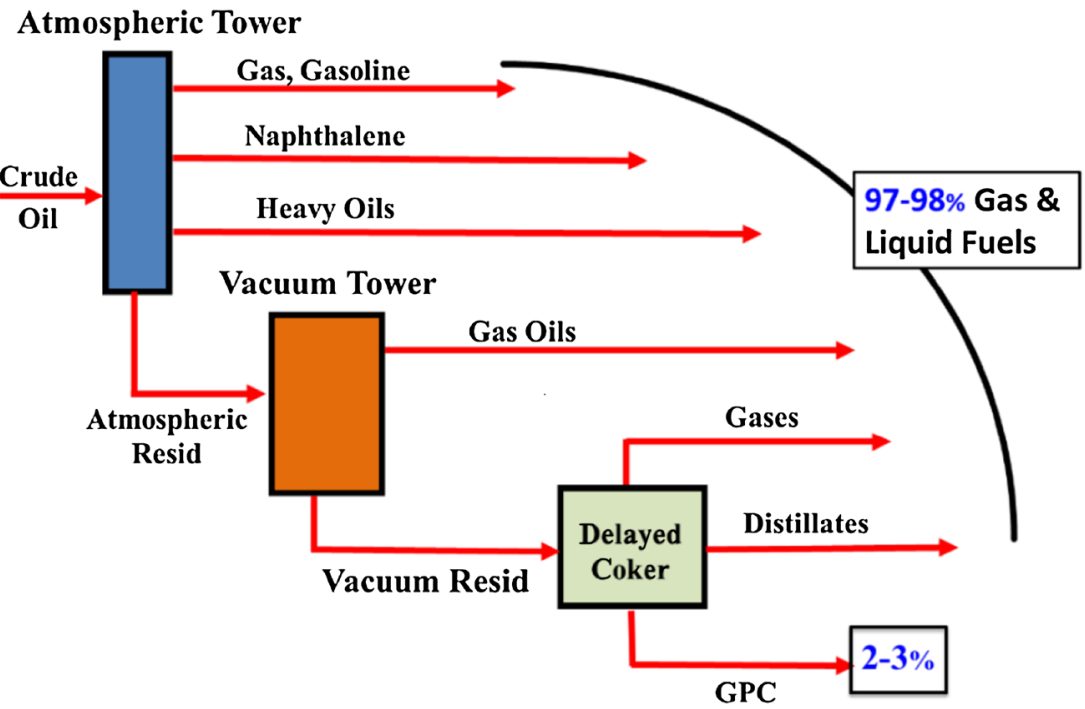

Fig. 3. Simplified refinery flow sheet with delayed coker showing relative product values.

resins and asphaltenes, which are large molecular weight precursors.

All GPC has residual volatile matter (VM) when it is cut from the drum. The VM level is dependent on the coking severity, but typical ranges are 9-14\%. Table I gives an example of three sponge cokes used by calciners for anode applications and a typical fuel-grade shot coke.

The Hardgrove Grindability Index (HGI) is a measure of hardness (lower value $=$ harder), and the data highlight the hardness of shot coke relative to sponge coke. Independent or merchant calciners (those not integrated with refineries) typically blend different quality GPCs together to produce CPC that meets anode specifications for $\mathrm{S}, \mathrm{V}, \mathrm{Ni}$, and other trace metals. The CPC product can also be blended by calciners prior to shipment.

The S, V, and Ni levels are determined by the crude blend used at the refinery with heavy, sour crudes containing higher levels of each. These three impurities are intimately bound in the carbon structure and cannot be removed. A more detailed 


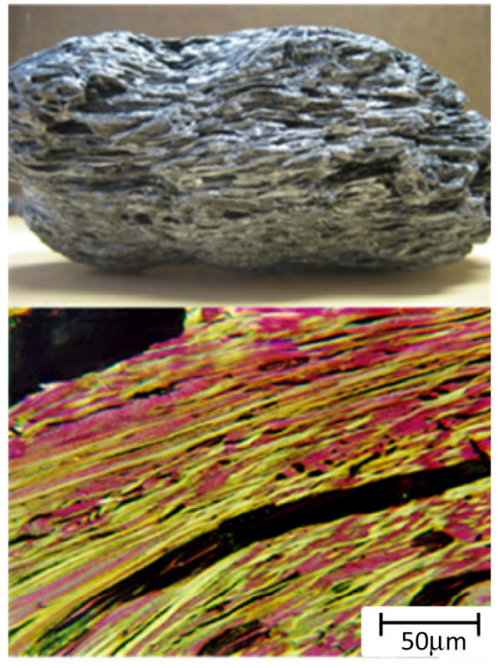

Needle

Anisotropic

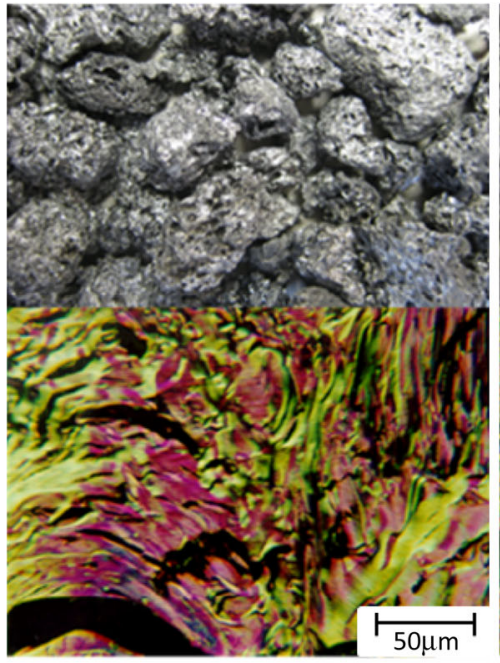

Sponge

Mixed

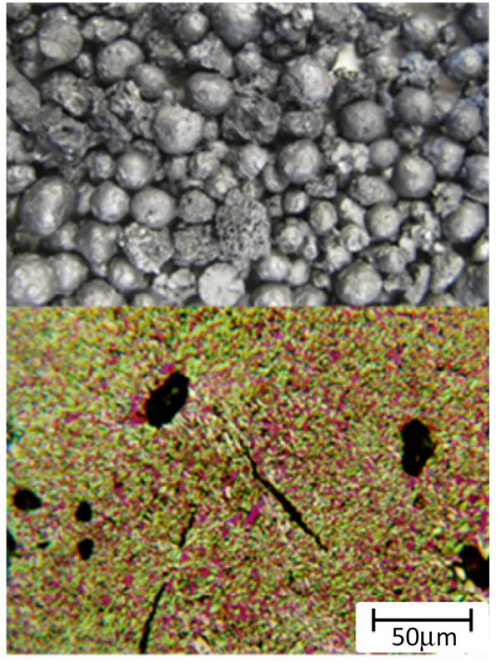

Shot

Isotropic

Fig. 4. Delayed coke types and optical textures.

Table I. Sponge GPC properties

\begin{tabular}{|c|c|c|c|c|}
\hline & \multicolumn{3}{|c|}{ Anode grade } & \multirow{2}{*}{$\begin{array}{c}\mathrm{Fuel}_{\text {Shot }} \mathrm{TiO}_{2} \\
\end{array}$} \\
\hline & Sponge A & Sponge B & Sponge C & \\
\hline Sulfur, \% & 0.5 & 2.0 & 4.6 & 6.5 \\
\hline Vanadium, ppm & 15 & 180 & 460 & 1930 \\
\hline Nickel, ppm & 65 & 170 & 190 & 410 \\
\hline Iron, ppm & 190 & 190 & 110 & 25 \\
\hline Calcium, ppm & 180 & 50 & 60 & 65 \\
\hline Silicon, ppm & 185 & 50 & 90 & 150 \\
\hline Sodium, ppm & 45 & 50 & 90 & 100 \\
\hline VM content, \% & 11.2 & 10.4 & 11.8 & 11.2 \\
\hline HGI & 105 & 95 & 80 & 35 \\
\hline
\end{tabular}

description of the sources of impurities in GPC can be found elsewhere. ${ }^{8}$ Sponge GPC used by the calcining industry is typically classified as low sulfur $(<2.5 \%$, e.g., cokes A and B in Table I) or high sulfur (>3.5\%, e.g., coke $\mathrm{C}$ in Table I).

\section{Coke Calcining}

GPC must be calcined or heat-treated at temperatures above $1200^{\circ} \mathrm{C}$ before it can be used to make anodes. It is necessary to drive out the VM during calcining so that the coke shrinks and densifies. Figure 5 shows the change in a coke's real density and bulk density during calcining. Anodes produced from GPC would result in uncontrolled shrinkage and cracking during baking, producing unacceptable quality. ${ }^{9}$ GPC is an electrical nonconductor and calcining transforms the structure into a more ordered, electrically conductive form of carbon with an acceptably low reactivity to air (oxygen) and $\mathrm{CO}_{2}$. The CPC used for anode production has low ash levels $(<0.3 \%)$ and a high carbon content (typically $>97 \%$ depending on the $\mathrm{S}$ level).

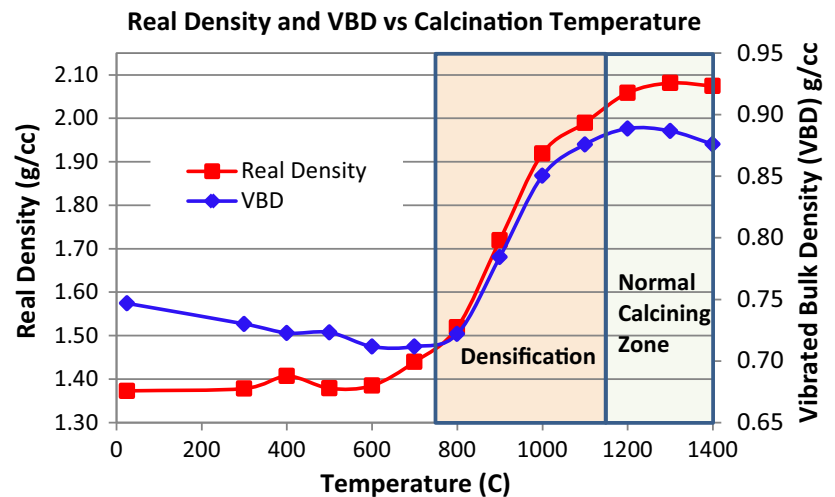

Fig. 5. Real density and vibrated bulk density changes during calcining.

Calciners always prefer GPC with a lower VM content because it results in a calcined product with lower porosity and higher bulk density. Figure 6 shows the relationship between the VM content of a single GPC source and the vibrated bulk density 
(VBD) of the CPC product. The VBD test is used widely in the industry as a simple, indirect measure of coke porosity. For an anode producer, higher VBD CPC can help in the production of higher density anodes, which is desirable to maximize the life of the anode in the cell before the anode butt is removed for recycling.

Table II shows the properties of CPC most commonly specified by aluminum smelters.

The real density is used as a measure of the degree of calcination, but other measurements such as Lc and specific electrical resistivity can also be used. There are at least four different bulk density tests in common use by the industry, and Table II shows the ASTM D4292 VBD test. Many of these tests are strongly influenced by minor sample preparation differences, ${ }^{10}$ which can make the comparison of results between laboratories difficult. A small amount of dedust oil (approximately 0.3 wt.\%) is almost always added to CPC to reduce dusting. One other property requested by some smelters is $\mathrm{CO}_{2}$ reactivity. This can be measured analytically using an ISO method ${ }^{11}$ or can be predicted quite reliably using an equation developed by

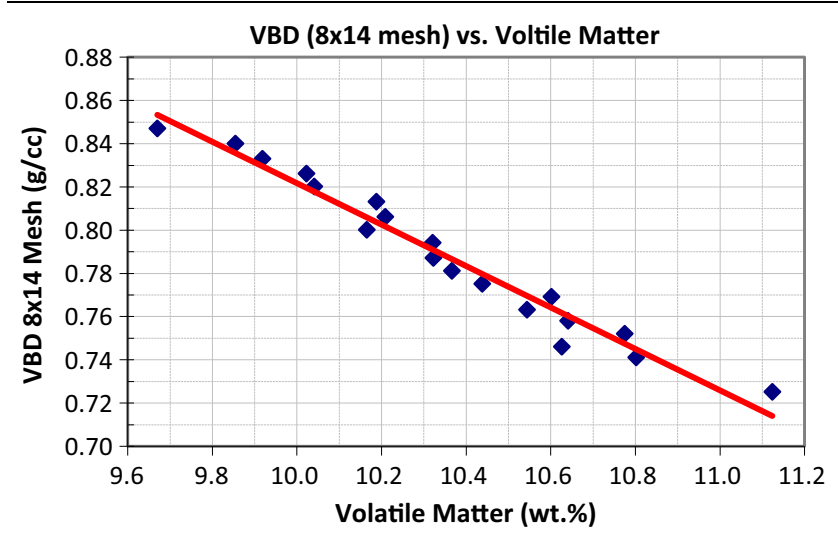

Fig. 6. Relationship between VM content and CPC VBD for a singlesource GPC.
R\&D Carbon based on the CPC S, Ca, and Na levels. ${ }^{12}$

\section{Coke Calcining Technology}

Early calcining of petroleum coke used both electric and gas fired vertical calciners ${ }^{2}$ the latter being a likely predecessor of the shaft calcining technology still used today in some parts of Russia and extensively in China. Electric calciners were used first, followed by the gas-fired Woodall-Duckam and Glover-West vertical types. ${ }^{3}$

\section{Rotary Kiln}

The first rotary kiln for calcining GPC was used at Great Lakes Carbon in $1935,{ }^{2}$ although rotary kilns had been used in the cement industry prior to that. Rotary kilns for CPC production are steel shells lined with high-temperature refractory brick; kilns can measure 30-85 m in length and 2.4-4.4 m in diameter. The kiln is sloped and turns slowly to move the coke through the kiln with a residence time of 45-60 min. The calcined coke exits the kiln at a temperature of $1200^{\circ} \mathrm{C}$ to $1350^{\circ} \mathrm{C}$ and is typically cooled by direct quenching with water in a rotary cooler.

Most kilns have a natural gas- or oil-fired burner at the discharge end that is used to heat the kiln from a cold start. It can also be used to provide additional heat for calcining, but most of the heat comes from the combustion of VM inside the kiln. Although rotary kiln technology has not changed significantly since its introduction, kilns have grown larger in size and most modern kilns are fitted with tertiary air fans as shown in Fig. 7. These are mounted on the kiln shell and blow air into the kiln in the zone where the volatile matter is combusted. This increases the efficiency of VM combustion and productivity from the kiln and reduces the need for supplemental fuel. ${ }^{13}$

Another modification in kilns that require supplemental fuel has been the introduction of oxygen

Table II. Typical specifications for CPC

\begin{tabular}{|c|c|c|c|}
\hline Property & Maximum or minimum & Typical specification & Broader specification \\
\hline Moisture, \% & $\operatorname{Max}$ & 0.3 & 0.5 \\
\hline Ash, \% & $\operatorname{Max}$ & 0.3 & 0.5 \\
\hline Sulfur, \% & $\operatorname{Max}$ & 3.0 & 3.5 \\
\hline Vanadium, ppm & Max & 350 & 500 \\
\hline Nickel, ppm & $\operatorname{Max}$ & 250 & 300 \\
\hline Iron, ppm & Max & 300 & 400 \\
\hline Calcium, ppm & Max & 200 & 250 \\
\hline Silicon, ppm & Max & 250 & 300 \\
\hline Sodium, ppm & Max & 150 & 200 \\
\hline Real density, g/cc & Min & 2.05 & 2.03 \\
\hline $\operatorname{VBD}(28 \times 48 \mathrm{mesh}=0.3-0.6 \mathrm{~mm})$ & Min & 0.85 & 0.82 \\
\hline Particle size $(+4$ mesh $=4.75 \mathrm{~mm})$ & Min & 25 & 25 \\
\hline Dedust oil, \% & Max & 0.3 & 0.5 \\
\hline
\end{tabular}




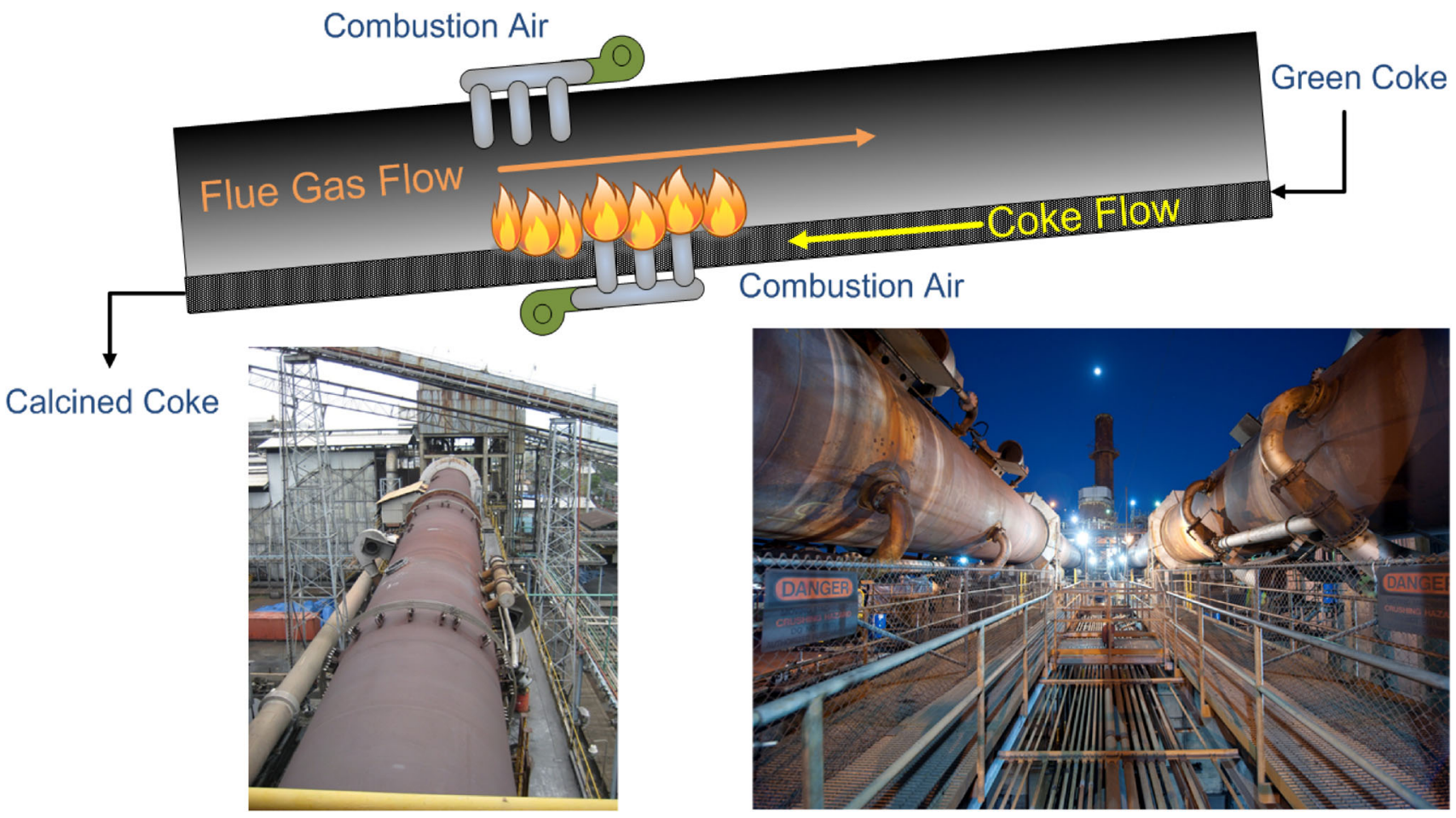

Fig. 7. Rotary kiln schematic and kilns equipped with tertiary air fans.

near the coke discharge end. This reduces the flue gas flow (compared with burning natural gas) and improves the product yield. It can also reduce operating costs depending on the relative costs of natural gas/fuel oil versus oxygen. ${ }^{14}$ Large, modern kilns are also fitted with internal refractory "lifters" to improve heat transfer to the coke bed and improve the bulk density of the calcined product. ${ }^{15}$

Many rotary kilns are built with waste heat energy recovery systems to capture heat from the hot flue gases exiting the kiln countercurrent to the coke bed. The heat is recovered from the combustion of VM in the GPC and the fine coke particles carried over from the kiln. Complete combustion takes place in a pyroscrubber and the hot flue gas passes through a heat recovery steam generator. The steam can be sold to nearby plants or used to generate power with a steam turbine generator. Waste heat-recovery systems have become pretty much mandatory for new calciner projects to improve the project economics.

Rotary kilns are still the predominant technology used to calcine coke outside China and they offer excellent economies of scale with a high level of automation. A single, modern kiln can produce up to $350,000 \mathrm{t} /$ year of CPC.

\section{Rotary Hearth Calciner}

The rotary hearth calciner shown in Fig. 8 is another calciner used around the world, although it is much less common than a rotary kiln. The design concept and calcining process of rotary hearth calciners have been described previously. ${ }^{16}$ The coke moves slowly from the outside perimeter of the rotary hearth kiln guided by rabbles toward the inner soak zone before exiting the hearth and being cooled with water in a rotating unit similar to the one described for the rotary kiln.

Rotary hearth calciners can also be configured to recover waste heat energy similar to rotary kilns. Compared with rotary kilns, rotary hearth calciners typically have a faster initial heat up rate for the coke, which can lead to lower CPC bulk densities when higher VM cokes are used. Rotary hearth calciners result in less fines loss from the coke bed, resulting in a higher recovery of calcined coke per ton of GPC. This is an economic advantage when operating the calciner but leads to a product with a higher fines content $(<0.5 \mathrm{~mm})$, which is not always desirable for an anode paste plant.

\section{Shaft Calcining}

Shaft calcining technology was initially transferred to China from Russia, and early shaft calciners were developed in Europe. A small shaft calciner designed and built by the Riedhammer company in the 1930s is still operating in Germany and used for the production of calcined anthracite. It is similar to some of the older shaft calciners operating in China but has been highly automated. Today, shaft calcining is the dominant technology in China, although rotary kiln calciners are also used.

In a shaft calciner, the VM from the GPC is combusted inside flue walls, meaning that there is no 


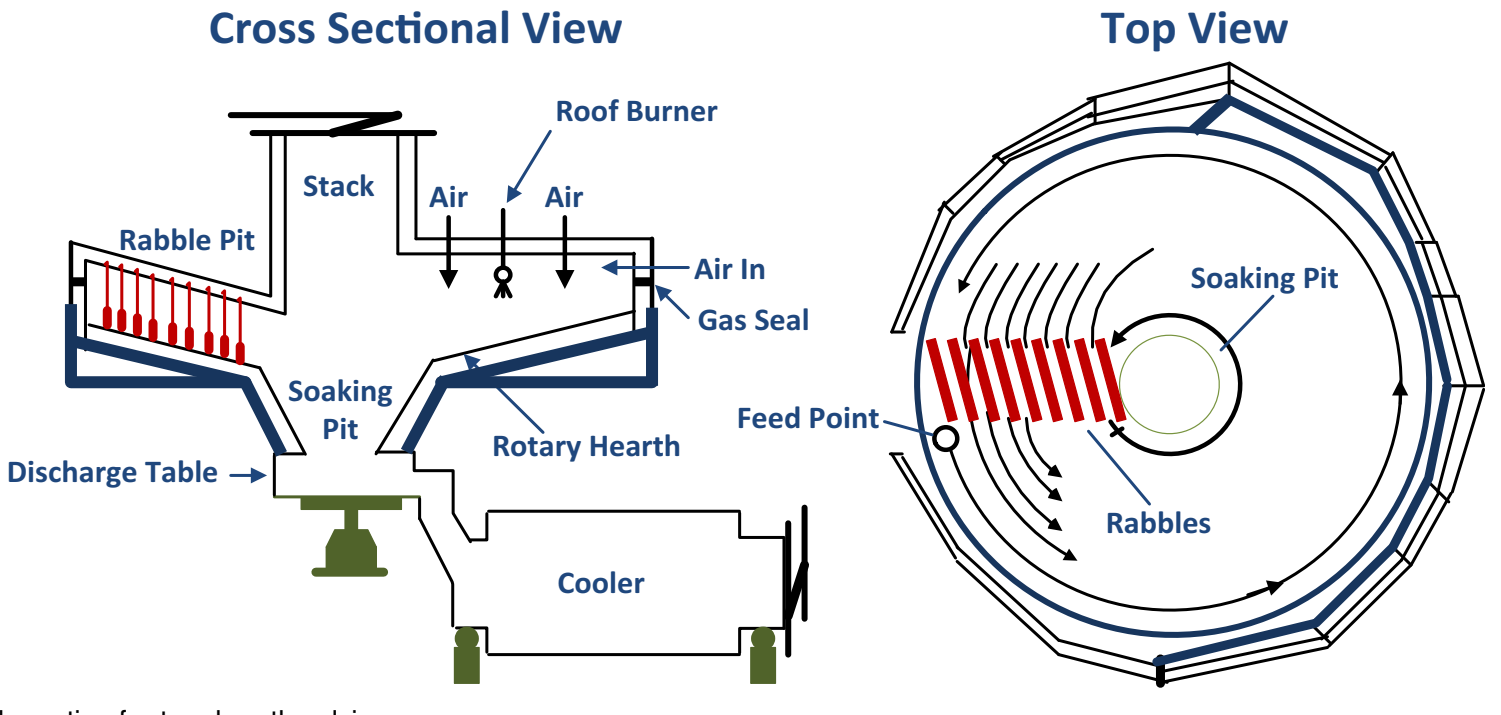

Fig. 8. Schematic of rotary hearth calciner.
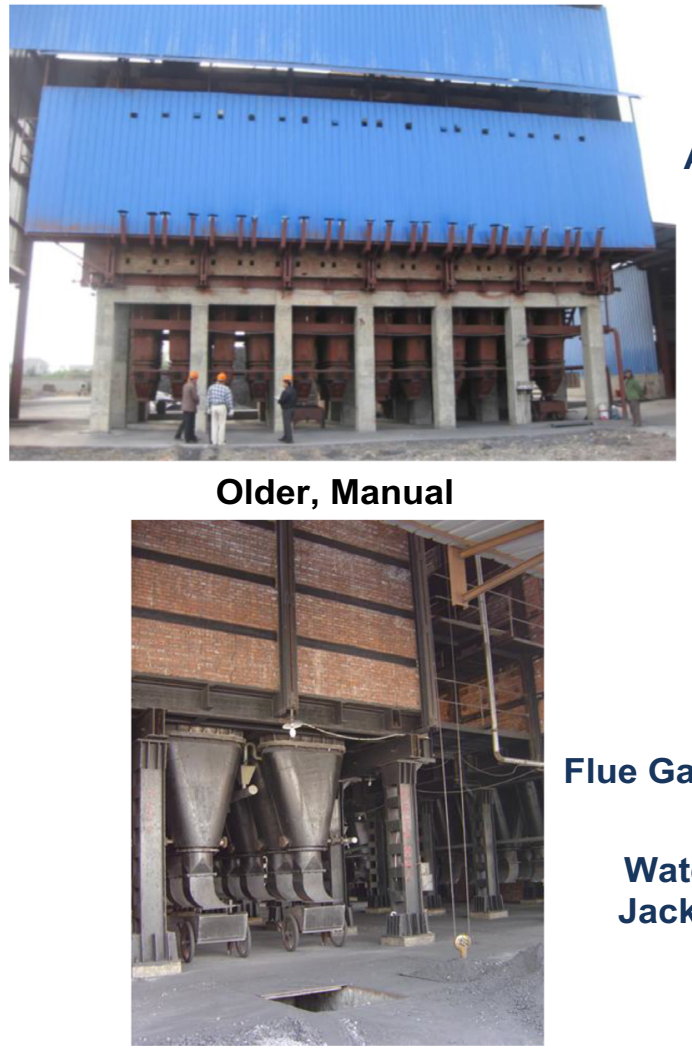

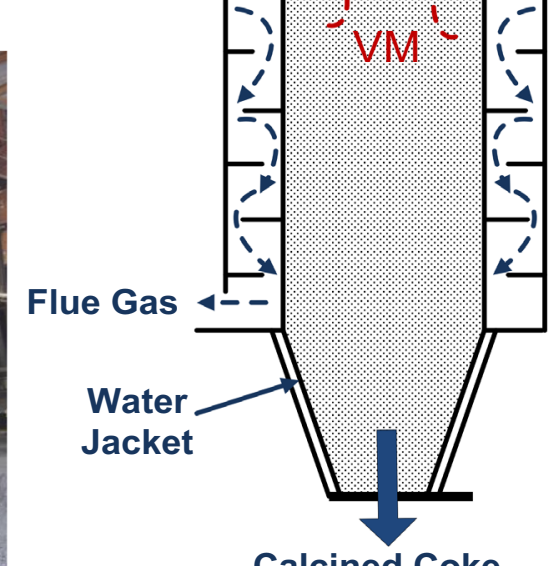

Calcined Coke

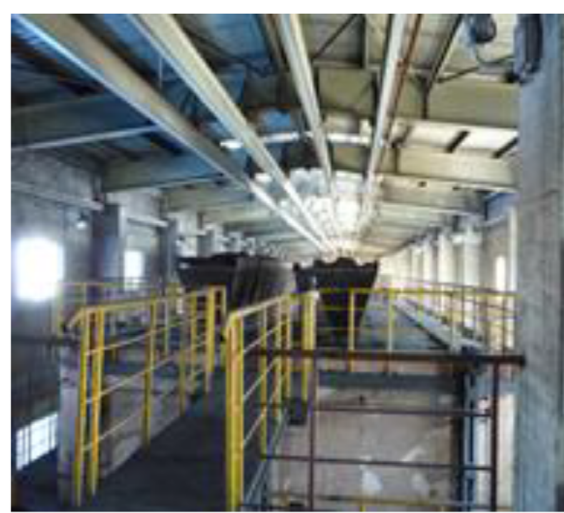

Modern, Automated

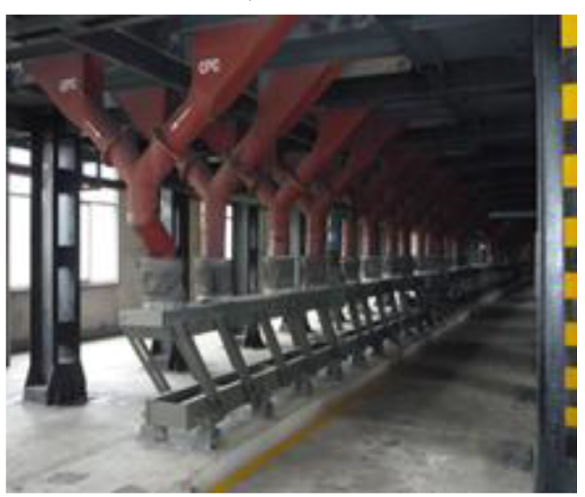

Fig. 9. Shaft calciner showing principal of operation in schematic.

contact between the flue gas stream and coke bed as there is in rotary kilns and rotary hearths. The coke moves very slowly down the shafts with a residence time in the range of $24-48 \mathrm{~h}$. The rate is controlled by the removal of CPC from the bottom of the shafts using a slide gate or rotary valve. The coke is cooled near the bottom of the shaft by a cooling water jacket.
Some older shaft calciners require a great deal of manpower to operate, but modern ones have automated feed and discharge systems, as shown in Fig. 9. A lot of the newer shaft calciners are also being built with waste heat-recovery systems.

Differences in the production and quality of shaft calcined coke versus rotary kiln and rotary hearth 


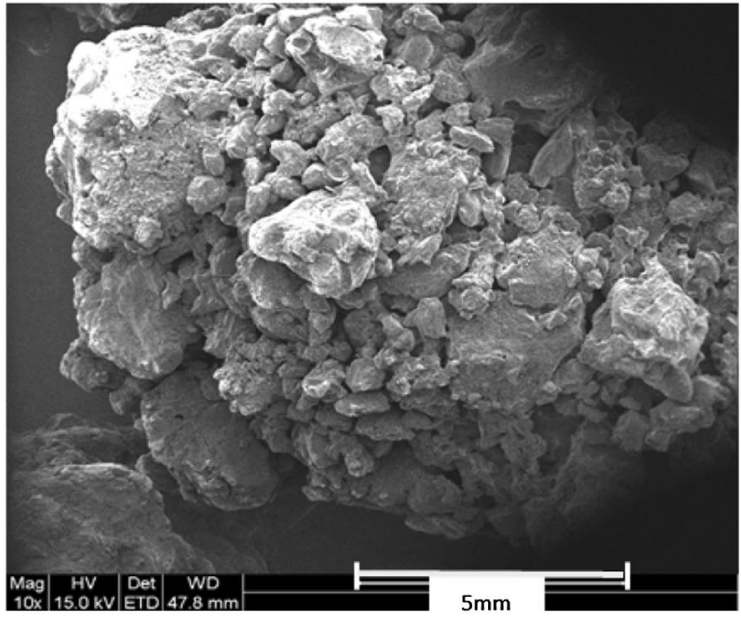

(a) Shaft Calciner

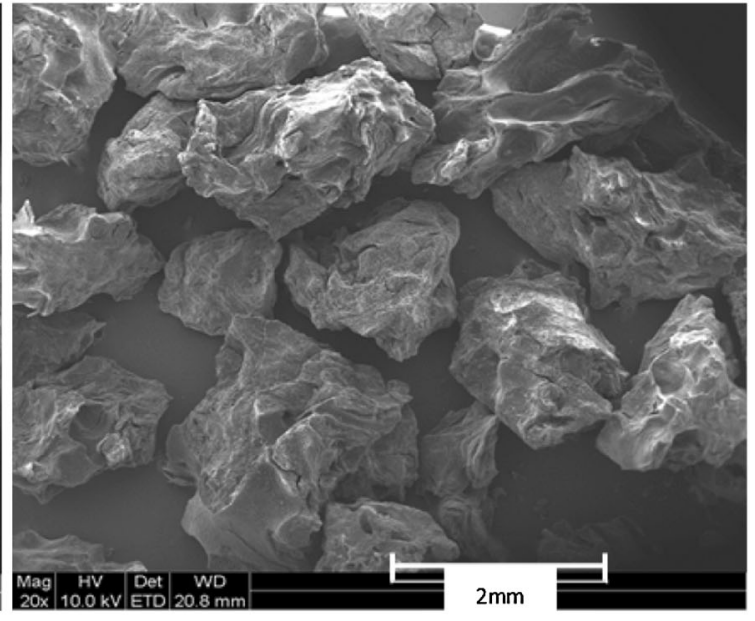

(b) Rotary Kiln

Fig. 10. SEM images of shaft (a) and rotary kiln CPC (b).

CPC have been well documented. ${ }^{16,17}$ Shaft CPC has a lower porosity and higher bulk density due to the slower heat-up rate and is coarser in particle size. Shaft CPC produced in older calciners can be dustier due to the agglomeration of fine particles on the surface of coarser particles. Newer shaft calciners with automated discharge systems and good dust collection systems do a better job of removing some of this dust. Figure 10 shows scanning electron microscopy (SEM) images of CPC produced in a shaft calciner (Fig. 10a) versus a rotary kiln (Fig. 10b), highlighting the agglomeration problem with shaft CPC.

Shaft CPC can sometimes cause problems during unloading due to its higher packing density, higher angle of repose, and poorer flow characteristics relative to rotary kiln calciners. Some anode plants have also experienced problems with silo discharge and dead storage. Some trace metal impurities like calcium can also be higher in shaft CPC. High $\mathrm{Ca}$ levels are quite common in Chinese GPC and CPC due to the frequent use of high total acid number crudes. $^{8}$ This is easy to monitor, but it is also important to examine differences in the impurity levels between coarse and fine particles. Elevated $\mathrm{Ca}$ levels in the fines fraction is undesirable because it increases anode $\mathrm{CO}_{2}$ reactivities. Table III shows an example of three different low $\mathrm{S}$, low $\mathrm{V}$ calcined cokes from northeast China with elevated Ca levels.

\section{Changes in Petroleum Coke Quality: Current and Future Challenges}

\section{Availability of Low-Sulfur GPC and Quality Changes}

The greatest change to have impacted the CPC industry in recent times has been the availability of suitable quality GPC. Over the last 10 years, gaining access to a reliable supply of low $\mathrm{S}$, low metals GPC has become more challenging, and the industry no longer enjoys a ready supply relative to the demand from the calcining and aluminum industries. The reasons for this have been well documented $^{18,19}$ and are driven by changes in crude oil quality and refining economics.

Most of the world's newly constructed refineries are configured to process heavy, sour crude oils that sell at a significant discount compared with light, sweet crudes. Many existing refineries, particularly in the United States, have made capital investments to allow the processing of more heavy, sour crudes like those from Canada. These changes have directly impacted the quality and volume of GPC produced. The general trend has been an increase in trace metals like $\mathrm{V}$ and $\mathrm{Ni}$ and an increase in $\mathrm{S}$ levels. The production of low S sponge coke $(<2.5 \%)$ in the United States has decreased by approximately $50 \%$ over the last 10 years. In many other parts of the of the world, including China, most of the growth in new GPC production is coke with higher S and metals levels and more isotropic textures.

The limited supply of low S GPC has driven prices higher. Figure 11 shows GPC price data published by the Jacobs Consultancy group in their quarterly PACE Blend report. The different categories (A-D) reflect different GPC sulfur levels. These can vary somewhat quarter to quarter, but approximate averages are shown. The record high prices in 2011 reflect the relative tightness of these cokes in the global supply. What is apparent from Fig. 11 is the sustained high differential in price between the low $\mathrm{S}$ category A cokes and the other higher S cokes since 2010

The CPC S level specification is the most critical for a smelter because it must operate within $\mathrm{SO}_{2}$ emission limits. $\mathrm{SO}_{2}$ limits vary by region but CPC S limits typically fall in the range of $1.8-3.0 \%$. Trace metal impurities in CPC are the next most important consideration, particularly $\mathrm{V}$ and $\mathrm{Ni}$ because 
Table III. Chemical analysis results of several Low S Chinese CPC sources

\begin{tabular}{|c|c|c|c|c|c|c|c|}
\hline $\mathrm{S}, \%$ & V, ppm & Ni, ppm & Ca, ppm & Fe, ppm & Si, ppm & Na, ppm & $\mathbf{R D}, \mathbf{g} / \mathbf{c c}$ \\
\hline 0.47 & 22 & 281 & 256 & 157 & 23 & 49 & 2.12 \\
\hline 0.43 & 20 & 378 & 394 & 168 & 100 & 30 & 2.13 \\
\hline 0.44 & 19 & 316 & 231 & 100 & 16 & 44 & 2.12 \\
\hline
\end{tabular}

$R D$ real density

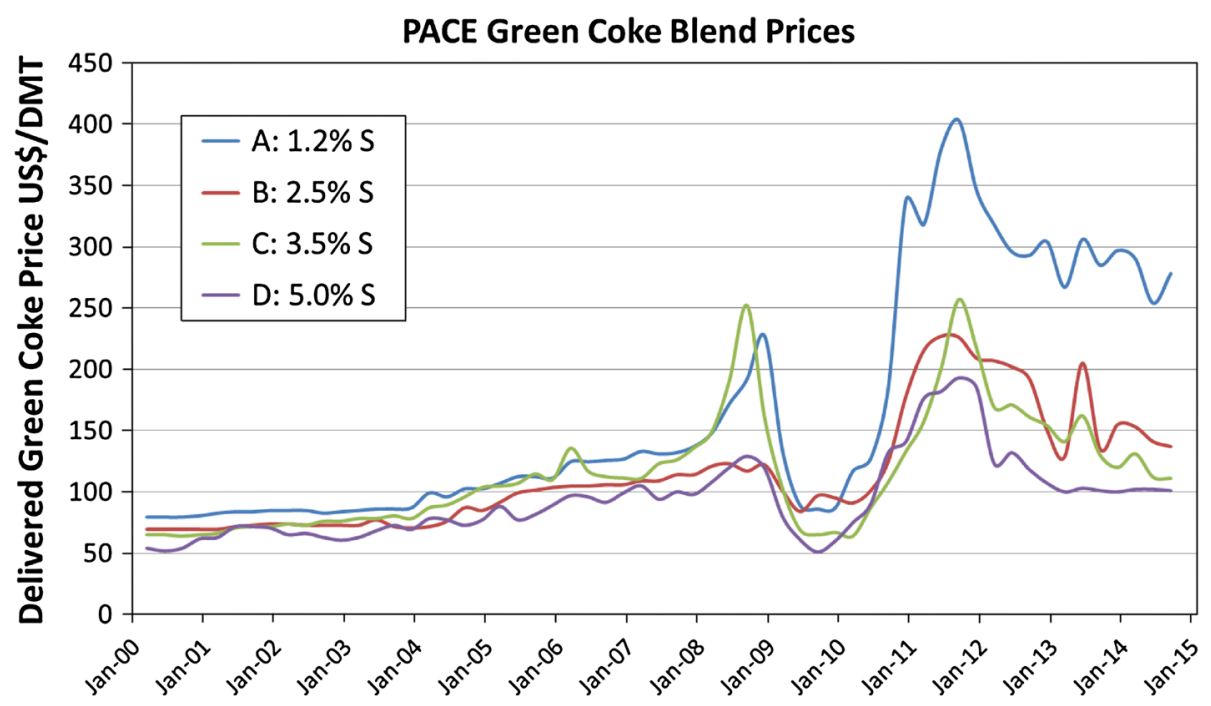

Fig. 11. Prices for freely negotiated, U.S. Gulf Coast GPC (courtesy Jacobs Consultancy).

they impact aluminum metal purity. It is desirable for trace metal impurities like $\mathrm{V}, \mathrm{Ni}, \mathrm{Ca}, \mathrm{Fe}$, and $\mathrm{Si}$ to be as low as possible. Historically, typical smelter CPC maximum specifications may have been $2.5 \%$ $\mathrm{S}, 250 \mathrm{ppm} \mathrm{V}, 180 \mathrm{ppm} \mathrm{Ni}, 150 \mathrm{ppm} \mathrm{Ca}, 250 \mathrm{ppm}$ $\mathrm{Fe}$, and $150 \mathrm{ppm} \mathrm{Si}$.

The relaxation of $\mathrm{CPC}$ specifications for $\mathrm{V}, \mathrm{Ni}$, and $\mathrm{S}$ has been underway for some time, but the number of smelters willing to relax specifications has increased since 2011 as a direct consequence of higher CPC prices. Calciners with the flexibility to source different GPC qualities can reduce raw material costs and offer lower priced CPC when one or more specifications are relaxed. The two specifications offering the greatest potential for cost savings are $\mathrm{V}$ and $\mathrm{S}$, particularly $\mathrm{V}$.

Historically, these two impurities have tended to follow each other in typical anode sponge cokes, but as shown in Fig. 12, these relationships are not as clear-cut today. The data are based on the analysis of a wide range of GPC sources used for anode CPC applications over the last 15 years. The relationships tend to be more scattered for some of the higher S and V GPC. The relationships can also vary by region as a result of crude oil differences. GPC produced with Marlim crude from Brazil, for example, shows a higher V/S ratio relative to most other GPC. Today, meeting historical V specifications of $200-300 \mathrm{ppm}$ requires a higher proportion of more expensive, low V/S cokes like the category A cokes shown in Fig. 11.

The trend graph in Fig. 13 shows how much average $\mathrm{V}$ levels have increased in anode grade coke shipped from Rain CII Carbon's US calciners to aluminum smelting customers over the last 20 years. Prior to 2003, average V levels were less than $200 \mathrm{ppm}$ and well below specification maximums, reflecting the ready supply of low V/S GPC. $\mathrm{V}$ levels have increased since that time, particularly over the last 4 years, and are shipped much closer to specification maximums today.

In addition to looking at $\mathrm{V}$ average data, it is also useful to examine the change in the distribution of $\mathrm{V}$ maximum specifications over the last 10 years from 2004 to 2014. Figure 14 shows the change in specifications for smelters supplied from the same U.S. calciners mentioned above. Today, several smelters are taking CPC with a V maximum specification of up to $500 \mathrm{ppm}$. It is important to note that some of these smelters blend the CPC with other lower V/S CPC, which is covered in the section below on blending. 


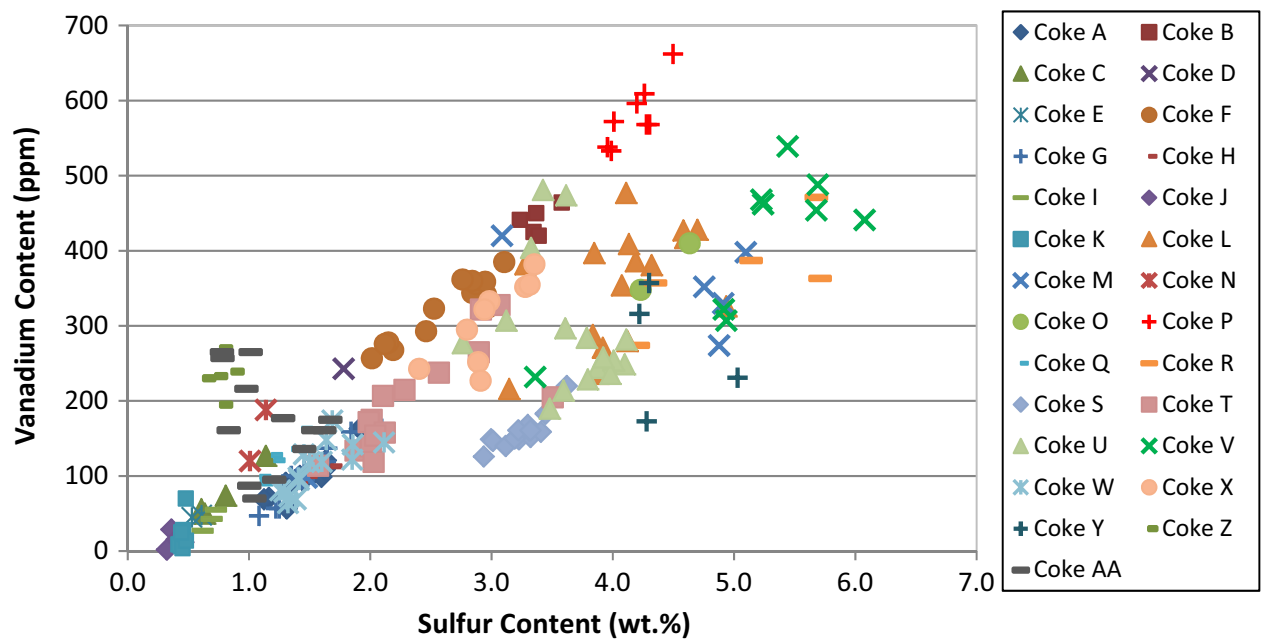

Fig. 12. V and S levels in GPC used in anode blends.

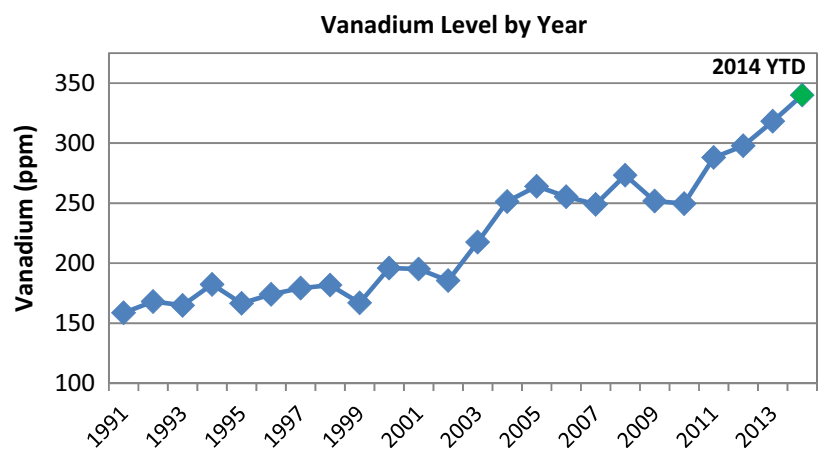

Fig. 13. Average $\mathrm{V}$ level of anode-grade CPC shipments.

Concerns about increasing $\mathrm{V}$ levels have been well documented in previous papers and a 2013 paper $^{20}$ contains a useful reference list. That paper provides a good case study example of a smelter that switched to a significantly higher $\mathrm{V}$ level coke due to a sudden and unexpected change in GPC quality. A relatively minor crude change at a refinery in close proximity to the calciner that supplied CPC to the smelter caused an increase of approximately $150 \mathrm{ppm}$ the GPC V level. The crude change provided a net benefit of \$10-12 million per month for the refinery in the form of reduced crude costs. This illustrates the compelling economics for refineries to optimize crude blends, and more examples are given in a refinery paper on this subject. ${ }^{21}$

The V specification for the above smelter was increased from $330 \mathrm{ppm}$ to $450 \mathrm{ppm}$ and the V level in the CPC shipped to the smelter increased rapidly, as shown in Fig. 15. The paper cited above ${ }^{20}$ described some of the work done at the smelter to improve operational practices, such as anode covering. Today, the smelter is operating as well as it ever has historically in terms of anode and smelter performance, and the higher V CPC continues to provide significant cost savings in the form of lower CPC costs.
For smelters producing P1020 primary aluminum product, higher $\mathrm{V}$ levels in CPC do not present any particular problems for metal purity. Higher V levels can be more problematic for smelters producing higher purity aluminum products depending on the end-use application. A significant body of work has already been undertaken on this issue, ${ }^{22-24}$ and more is underway. For some alloys, higher V levels may even be advantageous. ${ }^{25,26}$

The situation with CPC S increases is similar to $\mathrm{V}$, but less dramatic. Most smelters have a hard limit on $\mathrm{SO}_{2}$ emissions, which typically sets an upper limit on the CPC S specification unless the smelter has the ability to scrub $\mathrm{SO}_{2}$ from the baking furnace and potrooms. One trend that has emerged over the last 10 years is the request from smelters for both minimum and maximum $\mathrm{S}$ specifications. S in CPC and anodes has a beneficial effect on minimizing anode air and $\mathrm{CO}_{2}$ reactivity, as well as excess carbon consumption. ${ }^{27}$ These smelters prefer to operate with anodes at the highest $\mathrm{S}$ level allowed by the smelter's $\mathrm{SO}_{2}$ emission limit. The higher $\mathrm{S}$ can be particularly beneficial when the smelter experiences $\mathrm{Na}$ and $\mathrm{Ca}$ contamination from poorly cleaned butts. The $\mathrm{S}$ in the anode helps to mitigate the catalytic effect of these two impurities on air and $\mathrm{CO}_{2}$ reactivity.

One frequent question is whether there are any negative consequences of increasing anode $\mathrm{S}$ levels. Little data on this subject have been published, but one recent paper ${ }^{28}$ raised concerns about the potentially negative impact on cell current efficiencies, whereas earlier papers reported no impact. ${ }^{29}$ Thorne et al., on the other hand, ${ }^{30,31}$ reported correlations between anode reaction overpotentials and the level of impurities in CPC like S and V. Anodes made with higher $\mathrm{S}$ and $\mathrm{V}$ level $\mathrm{CPC}$ resulted in lower overpotentials, but it is not clear whether this is related to the impurity content or structure 

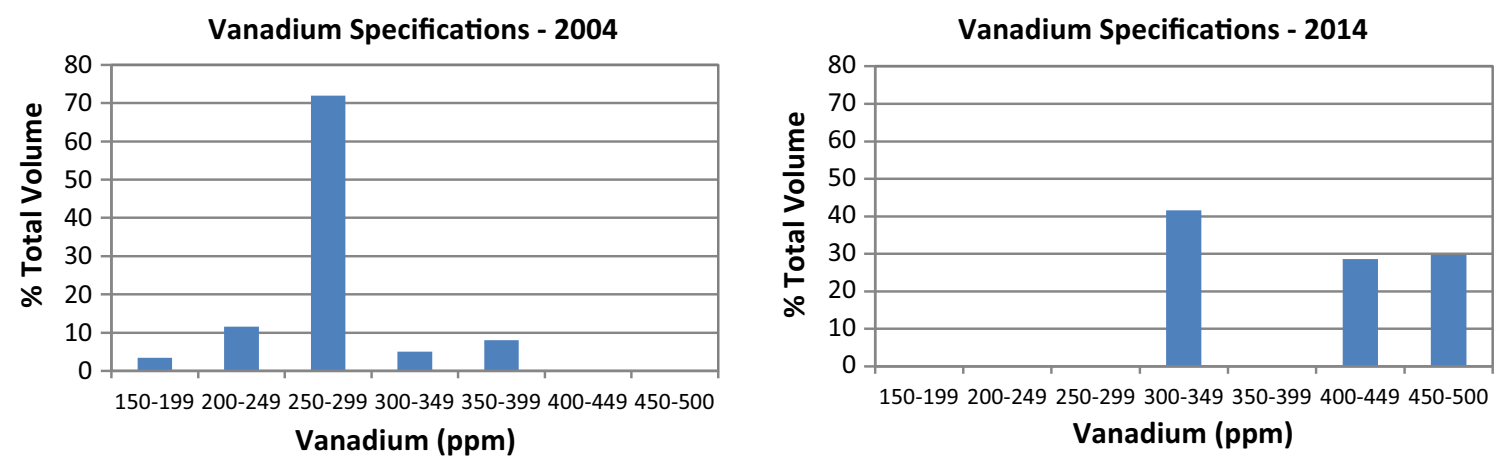

Fig. 14. Change in distribution of vanadium-level specifications.

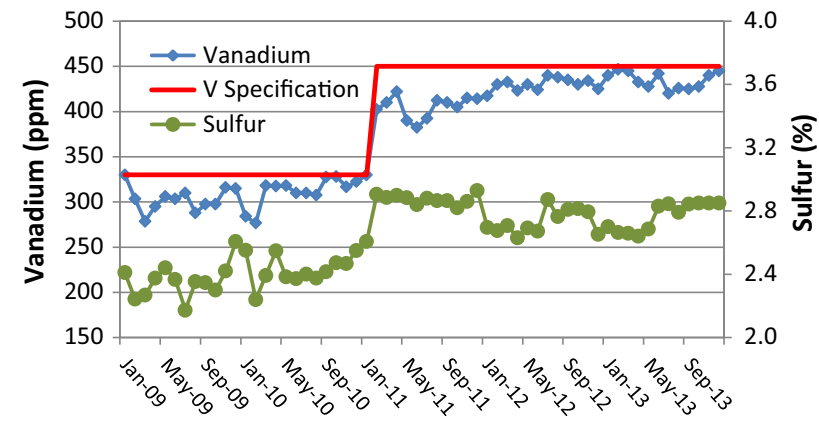

Fig. 15. $V$ and $S$ increase in CPC supplied to smelter and $V$ specification.

(anisotropic versus isotropic). More work is needed in this area.

The relaxation of smelter CPC specifications combined with the tight supply of low S GPC has resulted in a much wider range of GPC qualities being used in anode blends today. A good summary of the range of cokes being used can be found in a 2012 paper. ${ }^{19}$ One coke with a highly isotropic texture (non-shot with irregularly shaped particles) is now being used routinely as a blend component by several calciners at levels of up to $10-15 \%$. Previous concerns about thermal shock cracking with the use of isotropic cokes have not materialized at these relatively low levels, but other technology changes, such as the widespread use of anode slots, have significantly reduced, and in most cases eliminated, cracking. The use of isotropic cokes can provide both a raw material cost saving and an improvement in anode density, and testing with shot $\operatorname{coke}^{32}$ is continuing.

\section{Historical Perspective on Quality Changes}

At this point, it is worth reflecting on historical concerns about the lack of suitable quality GPC for anode production. This is not a new problem or concern and many papers can be found in the literature from the mid-1970s through the late 1980s that discuss increasing $\mathrm{S}, \mathrm{V}$, and Ni levels, as well as the threat of imminent shortages of GPC. Two examples are cited in the reference list, one from
$1977^{33}$ and one from $1989 .{ }^{34}$ The level of concern was high enough to initiate work on alternative carbons like solvent-refined coal. ${ }^{35}$

Despite these concerns, the industry did not experience any sustained shortages until around 2007, just before the global financial crisis (GFC). Both GPC and CPC were in short supply at that time and prices increased rapidly. The run-up in GPC prices is shown in Fig. 11. The GFC quickly changed that due to smelter closures and curtailments, which reduced the demand for CPC. The market tightened again in the 2010-2012 period, but continued smelter curtailments in the West in 2013 and 2014 have moderated the demand for CPC outside China. This situation will likely change again once aluminum prices recover, curtailed capacity is brought back online, and more new smelters are built. The sentiment for the long-term demand growth of aluminum remains very positive from this perspective.

\section{Impact of Shale Oil}

A more recent development beginning to impact GPC quality in the United States is the growth of shale oil production (also known as "tight oil"). Figure 16 shows the current and projected growth in shale oil production and illustrates why it is having a dramatic and positive impact on American energy independence, particularly when combined with a similar growth in shale gas production. This energy revolution is being driven by the development of two technologies now used in combination, namely horizontal drilling and hydraulic fracturing. This serves as a good example of how quickly technology breakthroughs can change an industry.

Shale oil is a light, sweet crude oil with a low specific gravity and low sulfur level. Given the declining supply of low S, low metals GPC in the United States, shale oil would initially seem to be good news for the production of low S GPC. The experience thus far has been the opposite and the reasons for this are well covered in Bartholomew's paper. ${ }^{18}$ In brief, shale oil contains very little "bottoms" (higher molecular weight hydrocarbons) and therefore makes very little coke. 


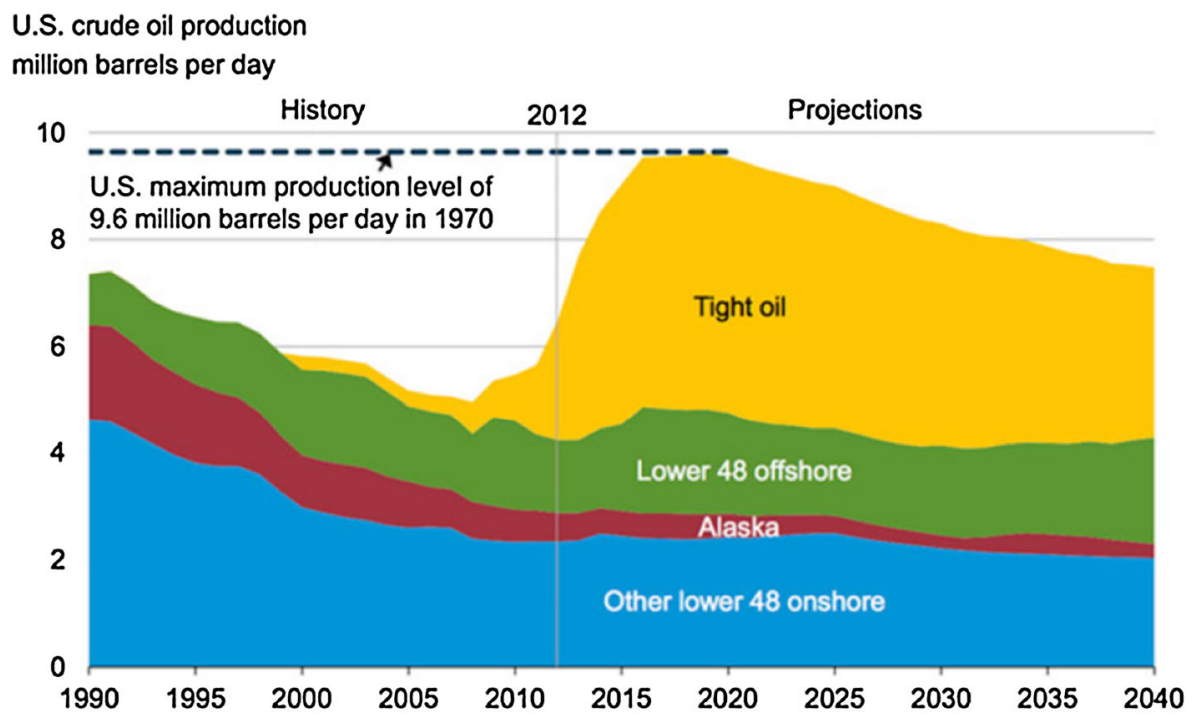

Source: EIA, Annual Energy Outlook 2014 Early Release

Fig. 16. Growth in shale oil (tight oil) production in the United States.

Table IV. Modeled impact of shale oil addition on GPC quality

\begin{tabular}{lcc}
\hline Crude slate & $\mathbf{2 0 1 0}$ & $\mathbf{2 0 1 2}$ \\
\cline { 1 - 1 } Percentage imported & 52 & 17 \\
Percentage domestic & 48 & 46 \\
Percentage shale & 0 & 37 \\
GPC volume and quality & & \\
MT/day & 951 & 934 \\
S\% & 2.87 & 3.75 \\
Vanadium, ppm & 272 & 393 \\
Nickel, ppm & 134 & 154 \\
\hline
\end{tabular}

$M T$ metric ton

Refineries using shale oil are using it as part of a crude blend to take advantage of its lower $\mathrm{S}$ and lower specific gravity by blending it with heavier, higher S crude oils. The impurities in the other crudes concentrate in the GPC product, which can increase $\mathrm{S}$ and $\mathrm{V}$ levels. For the refinery, this strategy can help reduce overall crude costs. Table IV shows the modeled impact on GPC quality and volume for a refinery switching out some of its low S imported crude in 2010 and replacing a portion of it with shale oil in 2012.

The refinery reduced the volume of expensive, imported light sweet crude from $52 \%$ to $17 \%$ by blending in $37 \%$ shale oil in 2012 . With the much lower S level and specific gravity of the shale oil, the refinery imported a cheaper, higher $\mathrm{S}$, heavy crude in 2012 and maintained the overall refinery $\mathrm{S}$ and API gravity target. The volume of coke produced remained the same because the higher proportion of imported crude made more GPC but the $\mathrm{S}, \mathrm{V}$ and $\mathrm{Ni}$ all increased. Although this is a model-generated example, the industry has seen an increase in the $\mathrm{S}$ level of some low $\mathrm{S}$ cokes in the United States by as much as $30-40 \%$ as a result of shale oil use. The impact on $\mathrm{V}$ and Ni levels has not been as significant.

The long-term impact of shale oil use on anode grade GPC production and quality in North America is not yet clear. Large quantities of shale oil are currently being moved by railcars and barges in the United States, but extensive pipeline networks are currently under construction. Once these pipelines are completed, shale oil may end up being a natural crude source for some refineries but not others. Some low $\mathrm{S}$ refineries may end up running a higher percentage of more traditional low S crudes, which could improve GPC quality and volumes. At least one American refinery is considering a capital investment to run $100 \%$ shale crude. This refinery has a delayed coker and no one is yet certain as to the quality of coke that would result, but it may produce a new source of good quality, low S GPC.

\section{Environmental Impact of Increasing Sulfur Levels}

All new calciners built in the world outside China in the last 20 years have been built with $\mathrm{SO}_{2}$ scrubbers. Retrofitting scrubbers to existing calciners is also becoming more common as environmental regulations tighten. Using the United States as an example, a new National Ambient Air Quality Standard (NAAQS) was proposed in 2010 and will come into full effect in mid-2018. The current NAAQS has an allowable maximum concentration of $\mathrm{SO}_{2}$ in the ambient air of $140 \mathrm{ppb}$ (parts per billion) averaged over a $24-\mathrm{h}$ period. The new NAAQS allows a concentration of $75 \mathrm{ppb}$ averaged over a 1 -h 


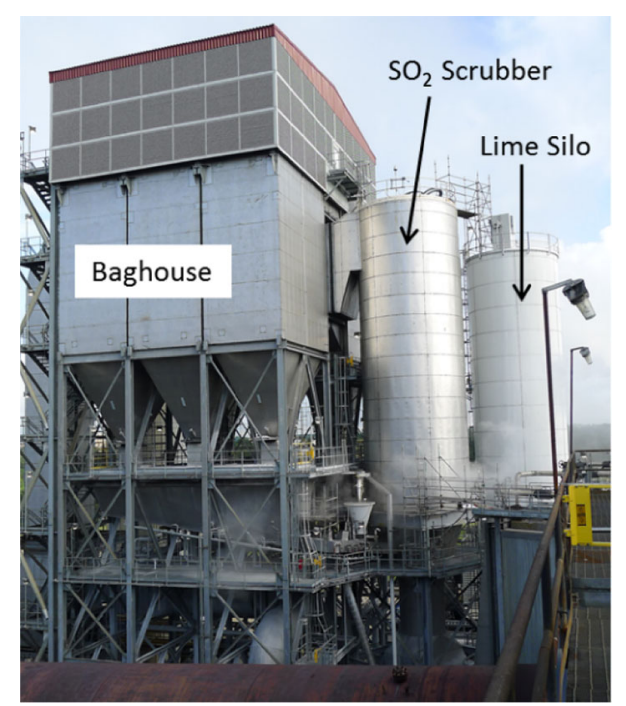

Fig. 17. Baghouse, $\mathrm{SO}_{2}$ scrubber, and lime silo ( $\mathrm{L}$ to $\left.\mathrm{R}\right)$ at Lake Charles calciner.

period. All states in the United States are now working on compliance plans to meet the new NAAQS. Rain CII Carbon has recently added a fluidized-bed $\mathrm{SO}_{2}$ scrubber to its Lake Charles calciner in Louisiana (shown in Fig. 17) and is in the process of adding a similar scrubber to its Chalmette calciner in readiness for the new NAAQS.

As average CPC S levels continue to trend upward, the need for $\mathrm{SO}_{2}$ scrubbing at smelters will also increase. Long term, we can probably expect new smelters to require the addition of $\mathrm{SO}_{2}$ scrubbing given that scrubbing technology is mature and readily available even if it does add to capital and operating costs. Alcoa recently reported on a new $\mathrm{SO}_{2}$ scrubbing technology it is developing as a potential retrofit for smelters to reduce $\mathrm{SO}_{2}$ emissions. ${ }^{36}$

\section{Blending CPC at Smelters}

Coke blending at smelters is not a new idea, ${ }^{37}$ but more and more smelters are either being built with blending systems or are adding them as retrofit projects. A primary goal is to allow the blending of CPC from different suppliers, which gives the smelter the flexibility to source different quality CPC from the most geographically favorable regions. A common practice is to source low $\mathrm{S}$ and low metals CPC from one region for blending with lower cost, higher S and V CPC from another region.

For smelters using a combination of shaft CPC and rotary kiln/rotary hearth CPC, it is important that the smelter has the ability to blend these cokes thoroughly. The porosities and bulk densities of the cokes are very different and will result in large pitch level and anode density variations if they are processed on a campaign basis. Differences in the fines levels and hardness levels of the cokes can also lead to greater variation in fraction preparation, particularly with respect to the ball mill operation. Blending the cokes at a more or less constant ratio can help minimize these problems and improve anode quality and consistency. Recent papers ${ }^{38,39}$ provide some good smelter data on the benefits of blending CPC.

Blending systems at most smelters are usually relatively simple weigh belt systems. Some smelters have adopted more sophisticated blending strategies by concentrating different coke types in different parts of the aggregate recipe. In one example, ${ }^{40}$ the highest VBD coke is concentrated in the coarser fractions of the recipe to maximize anode density. In another example, ${ }^{41}$ higher $\mathrm{S}$, lower $\mathrm{CO}_{2}$ reactivity cokes are used in the ball mill fines fraction to reduce the reactivity of the binder matrix, which is usually the highest reactivity phase in the anode.

As smelters get larger in size, the need to use multiple coke suppliers to mitigate supply risks and optimize economics will continue to increase. The capital investment required to add a CPC blending system is not high relative to the total smelter investment cost, and it has a big payback in terms of consistency if the smelter uses a blend of low and high $\mathrm{S}$ coke and/or a blend of rotary/shaft calcined coke.

\section{SUMMARY AND CONCLUSION}

GPC and CPC production have continued to evolve over the last century of aluminum production. During the last 10 years, the industry has started using a wider range of GPC qualities than it has historically, and the availability of good-quality GPC remains challenging as refiners optimize their economics by sourcing lower cost crudes. In the United States, shale oil is beginning to impact both the volume and quality of GPC produced, but the long-term impact remains unclear.

More smelters are blending CPC from different suppliers and this trend is expected to continue along with an increase in the sophistication of blending practices. The need to blend becomes even more important for smelters using a combination of rotary and shaft CPC as a result of the different porosity and bulk density profiles of these cokes.

The trend toward increasing CPC sulfur levels in combination with tightening $\mathrm{SO}_{2}$ emissions limits is driving more calciners to add $\mathrm{SO}_{2}$ scrubbing, and it is now a mandatory technology for new calcining plants. In the future, we are likely to see more smelters built with $\mathrm{SO}_{2}$ scrubbing, and work is underway on developing alternative scrubbing technologies.

The aluminum industry continues to adapt well to changes in CPC quality such as higher $\mathrm{V}$ and $\mathrm{S}$ levels and more isotropic textures, and many smelters have pursued a strategy of relaxing specifications to procure lower cost CPC. In 2013, the world produced approximately 115 million DMT of GPC, and only about $25 \%$ of this was used by 
calciners for production of CPC for aluminum and other industries. There is no shortage of GPC; rather, it is a matter of the industry continuing to use what is available.

Demand for CPC outside China has moderated over the last couple of years with the curtailment of smelting capacity in the West, but this looks set to change in the near future. Demand for aluminum exceeded primary aluminum production for the first time in many years in 2014. Once existing capacity is restarted and/or new capacity is built to satisfy the forecasted aluminum demand, we should expect the supply and demand balance for CPC and GPC to tighten once again with the usual market impact.

\section{OPEN ACCESS}

This article is distributed under the terms of the Creative Commons Attribution License which permits any use, distribution, and reproduction in any medium, provided the original author(s) and the source are credited.

\section{REFERENCES}

1. J. Keniry, Proc. Seventh Australasian Aluminium Smelting Technology Conference and Workshop, ed. B.J. Welch and M. Skyllas-Kazacos (Sydney, Australia: University of New South Wales, 2001), pp. 584-597.

2. W.S. Petersen and R.E. Miller, eds., Hall Héroult Centennial: First Century of Aluminum Process Technology 18861986 (Warrendale, PA: TMS, 1986), pp. 130-143.

3. C.L. Mantell, Carbon and Graphite Handbook (New York, NY: Wiley, 1968), Chap. 15.

4. P.J. Ellis and C.A. Paul (Paper presented at the AIChE 1998 Spring National Meeting, New Orleans LA, 8-12 March 1998).

5. P. Rhedey and D. DuTremblay, Light Metals 1977, ed. K.B. Higbie (New York, NY: The Metallurgical Society of AIME, 1977), pp. 301-315.

6. A. Innus, A. Jomphe, and H. Darmstadt, Light Metals 2013, ed. B. Sadler (Warrendale, PA: TMS, 2013), pp. 1069-1073.

7. K. Neyrey, L. Edwards, A. Ross, and F. Vogt, Light Metals 2005, ed. H. Kvande (Warrendale, PA: TMS, 2005), pp. 607612 .

8. L. Edwards, Light Metals 2014, ed. J. Grandfield (Warrendale, PA: TMS, 2014), pp. 1093-1098.

9. Q. Nguyen, Light Metals 1985, ed. H.O. Bohner (Warrendale, PA: TMS, 1985), pp. 903-913.

10. M. Lubin, L. Edwards, and L.-P. Lossius, Light Metals 2013, ed. B. Sadler (Warrendale, PA: TMS, 2013), pp. 1063-1068.

11. ISO 12981-1, Carbonaceous Materials Used in the Production of Aluminium-Calcined Coke-Determination of the Reactivity to Carbon Dioxide. Part 1-Loss in Mass Method, 2011.

12. S. Hume, W.K. Fischer, R.C. Perruchoud, and B.J. Welch, Light Metals 1993, ed. S.K. Das (Warrendale, PA: TMS, 1993), pp. 525-531.

13. F.J. Farago and R.R. Sood, Light Metals 1976, ed. S.R. Leavitt (New York, NY: The Metallurgical Society of AIME, 1976), pp. 351-362.

14. D.R. Mason and H.C. Rolseth, Light Metals 1985, ed. H.O. Bohner (Warrendale, PA: TMS, 1985), pp. 863-869.

15. M.F. Vogt, G.R. Jones, and G.A. Tyler, Light Metals 1984, ed. J.P. McGeer (Warrendale, PA: TMS, 1984), pp. 16971714 .
16. K. Ries, Light Metals 2009, ed. G. Bearne (Warrendale, PA: TMS, 2009), pp. 945-950.

17. L. Edwards, Light Metals 2011, ed. S.J. Lindsay (Warrendale, PA: TMS, 2011), pp. 895-900.

18. K. Bartholomew, Light Metals 2013, ed. B. Sadler (Warrendale, PA: TMS, 2013), pp. 15-20.

19. L. Edwards, N. Backhouse, H. Darmstadt, and M-J Dion, Light Metals 2012, ed. C.E. Suarez (Warrendale, PA: TMS, 2012), pp. 1207-1212.

20. A. Weber, J. Gavin, C. Coney, W. Marcrum, L. Crabtree, and L. Edwards, Light Metals 2013, ed. B. Sadler (Warrendale, PA: TMS, 2013), pp. 21-25.

21. T.W. Dixon, Light Metals 2009, ed. G. Bearne (Warrendale, PA: TMS, 2009), pp. 941-944.

22. J. Grandfield, L. Sweet, A. Beer, S. Zhu, X. Chen, and M. Easton, Light Metals 2014, ed. J. Grandfield (Warrendale, PA: TMS, 2014), pp. 969-974.

23. J. Grandfield, L. Sweet, C. Davidson, J. Mitchell, A. Beer, S. Zhu, X. Chen, and M. Easton, Light Metals 2013, ed. B. Sadler (Warrendale, PA: TMS, 2013), pp. 39-45.

24. S. Zhu, J.-Y. Yao, L. Sweet, M. Easton, J. Taylor, P. Robinson, and N. Parson, JOM, 65, 584 (2013).

25. G. Jha, S. Ningileri, X. Liu, and R. Bowers, Light Metals 2013, ed. B. Sadler (Warrendale, PA: TMS, 2013), pp. 929934.

26. G. Jha, F. Cannova, and B. Sadler, Light Metals 2012, ed. C.E. Suarez (Warrendale, PA: TMS, 2012), pp. 1303-1306.

27. Z. Kuang and J. Thonstad, Carbon 33, 1479 (1995).

28. S. Pietrzyk and J. Thonstad, Light Metals 2012, ed. C.E. Suarez (Warrendale, PA: TMS, 2012), pp. 659-664.

29. E. Barrillon and J. Pinoir, Light Metals 1977, ed. K.B. Higbie (New York: The Metallurgical Society of AIME, 1977), pp. 289-299.

30. R.J. Thorne, C. Sommerseth, A.M. Svensson, E. Sandnes, L.P. Lossius, H. Linga, and A.P. Ratvik, Light Metals 2014, ed. J. Grandfield (Warrendale, PA: TMS, 2014), pp. 12131217.

31. R.J. Thorne, C. Sommerseth, E. Sandnes, O. Kjos, T.A. Aarhaug, L.P. Lossius, H. Linga, and A.P. Ratvik, Light Metals 2013, ed. B. Sadler (Warrendale, PA: TMS, 2013), pp. $1207-1211$.

32. L. Edwards, F. Vogt, M. Robinette, R. Love, A. Ross, M. McClung, R.J. Roush, and W. Morgan, Light Metals 2009, ed. G. Bearne (Warrendale, PA: TMS, 2009), pp. 985-990.

33. H. Brandt, Light Metals 1977, ed. K.B. Higbie (New York, NY: The Metallurgical Society of AIME, 1977), pp. 333-349.

34. U. Mannweiler, W. Schnidt-Hatting, D. Rodriguez, and A. Maitland, Light Metals 1989, ed. P.G. Campbell (Warrendale, PA: TMS, 1989), pp. 449-454.

35. E. Hollingshead and P. Rhedey, Light Metals 1985, ed. H.O. Bohner (Warrendale, PA: TMS, 1985), pp. 589-605.

36. "Alcoa pilots new in-duct scrubber technology." Light Metal Age 71 (5) (2013).

37. L. Edwards, F. Vogt, and J. Wilson, Light Metals 2001, ed. J. Anjier (Warrendale, PA: TMS, 2001), pp. 689-694.

38. B. Ndjom, M.S. Malik, A. Al Marzouqi, T.K. Sahu, and S.A. Rabba, Light Metals 2013, ed. B. Sadler (Warrendale, PA: TMS, 2013), pp. 1105-1110.

39. E.G.M. Mofor, S. Akhmetov, T.K. Sahu, J. Blasques, D. Whitfield, G. Meintjes, K.S. Rajwinder, A. Jassim, S.A. Rabba, H. Devadiga, and K. Al Aswad, Light Metals 2014, ed. J. Grandfield (Warrendale, PA: TMS, 2014), pp. 11991202.

40. C. Kato, H. Truci, F. Figueiredo, A. Nascimento, and V. Piffer, Light Metals 2007, ed. M. Sørlie (Warrendale, PA: TMS, 2007), pp. 891-894.

41. M. Gendron, S. Whelan, and K. Cantin, Light Metals 2008, ed. D.H. DeYoung (Warrendale, PA: TMS, 2008), pp. 861864 . 